\title{
Effect of field pea grown as a catch crop on health status of spring barley
}

\author{
Wpływ grochu siewnego uprawianego w międzyplonie ścierniskowym \\ na zdrowotność jęczmienia jarego
}

\author{
Grzegorz Lemańczyk ${ }^{1}$, Edward Wilczewski
}

\begin{abstract}
Summary
Spring barley was grown on the proper black soil, on the experimental plots in Szadłowice (52 $\left.50^{\prime} \mathrm{N}, 18^{\circ} 20^{\prime} \mathrm{E}\right)$ in 2009-2011. The aim of this study was to compare the effect of field pea grown as a catch crop (catch crop ploughed in autumn; catch crop as a mulch; without a catch crop - control) on the occurrence of diseases in spring barley cultivar Tocada sown the following year. The catch crop decreased stem base infection caused by Fusarium spp. and Cochliobolus sativus. However, it also contributed to an increase in infection of leaves with Blumeria graminis, the pathogen than causes powdery mildew. The most symptoms of powdery mildew were recorded on the mulched plots. There was no significant effect of catch crop on the occurrence of other diseases of roots, stem base, leaves and spikes. The pathogens occurring in infected spring barley roots were predominantly Gaeumannomyces graminis and Glomerella graminicola, while Fusarium species, C. sativus and Rhizoctonia solani were isolated less frequently. Diseased stems of barley were settled the most often by F. culmorum, C. sativus, G. graminicola and Gibberella avenacea. Oculimacula yallundae, Rhizoctonia spp., Aureobasidium pullulans and Microdochium bolleyi were isolated much less frequently.
\end{abstract}

Key words: field pea; catch crop; mulch; spring barley; health status; diseases; fungi

\section{Streszczenie}

Jęczmień jary uprawiano w latach 2009-2011, na poletkach doświadczalnych w Szadłowicach (5250' N, 18²0' E), na czarnej ziemi typowej. Celem badań było określenie wpływu grochu siewnego uprawianego w międzyplonie ścierniskowym (międzyplon przyorany jesienią; międzyplon jako mulcz; bez międzyplonu - kontrola) na występowanie chorób w jęczmieniu jarym odmiany Tocada wysiewanym w następnym roku. Zastosowanie międzyplonu ścierniskowego spowodowało spadek porażenia podstawy źdźbła jęczmienia przez Fusarium spp. i Cochliobolus sativus. Międzyplon przyczynił się jednak do wzrostu porażenia liści przez Blumeria graminis. Najwięcej objawów mączniaka prawdziwego zbóż i traw stwierdzono na jęczmieniu uprawianym po międzyplonie ścierniskowym pozostawionym na zimę jako mulcz. Nasilenie pozostałych chorób występujących na korzeniach, podstawie źdźbła, liściach i kłosach jęczmienia nie zależało od zastosowanego międzyplonu ścierniskowego. Wśród patogenicznych grzybów występujących na porażonych korzeniach jęczmienia dominowały Gaeumannomyces graminis i Glomerella graminicola; znacznie mniej izolowano Fusarium spp., C. sativus i Rhizoctonia solani. Źdźbła jęczmienia z objawami chorobowymi najczęściej zasiedlone były przez F. culmorum, C. sativus, G. graminicola i Gibberella avenacea. Znacznie rzadziej wyodrębniano Oculimacula yallundae, Rhizoctonia spp., Aureobasidium pullulans i Microdochium bolleyi.

Słowa kluczowe: groch; międzyplon ścierniskowy; mulcz; jęczmień jary; zdrowotność; choroby; grzyby

\footnotetext{
Uniwersytet Technologiczno-Przyrodniczy im. Jana i Jędrzeja Śniadeckich w Bydgoszczy

Kordeckiego 20, 85-225 Bydgoszcz

${ }^{1}$ Zakład Fitopatologii Molekularnej

grzegorz.lemanczyk@utp.edu.pl

Katedra Agrotechnologii
} 


\section{Wstęp / Introduction}

Rozprzestrzenianie patogenów i nasilenie powodowanych przez nie symptomów chorobowych jest zależne od różnych czynników, a jednym z nich jest zmianowanie. Od kilkunastu lat zboża wiechlinowe zdominowały strukturę zasiewów w Polsce. W 2012 roku zajmowały one $73,8 \%$ ogólnej powierzchni zasiewów. Najczęściej uprawianym zbożem była pszenica $(27,0 \%)$, a na kolejnych miejscach pod tym względem notowano mieszanki zbożowe (16,6\%) i jęczmień (15,1\%) (GUS 2012). Jęczmień, podobnie jak pszenica, należy do zbóż często atakowanych przez patogeny (Walters i wsp. 2012; Kurowski i wsp. 2013). Rośliny te cechuje duża wrażliwość na choroby podsuszkowe, których nasilenie zwiększa się w warunkach stosowania płodozmianów i monokultur zbożowych (Mathre 1997; Bockus i wsp. 2010). Uprawa jęczmienia po roślinach zbożowych może wpływać na wzrost zachorowań korzeni i podstawy źdźbeł wskutek porażenia przez patogeny grzybowe (Lemańczyk i Wilczewski 2006). Mniej jest natomiast informacji na temat występowania patogenów na liściach i kłosach, które zdaniem Waltersa i wsp. (2012) zależne jest w znacznie mniejszym stopniu od zmianowania.

W celu ograniczenia negatywnych skutków nadmiernego udziału zbóż w zasiewach i systematycznego wnoszenia do gleby resztek pozbiorowych zainfekowanych przez patogeny powodujące choroby podstawy źdźbła, celowe jest poszukiwanie metod umożliwiających ograniczenie ich rozwoju. Jedną $\mathrm{z}$ nich może być dostarczenie do gleby materii organicznej $\mathrm{z}$ roślin, które nie są atakowane przez patogeny zbóż. Bailey i Lazarovits (2003) podają, że intensywny rozwój organizmów saprotroficznych występujący po wprowadzeniu do gleby materii organicznej wywołuje działanie antagonistyczne w stosunku do patogenów.

Relatywnie tanim źródłem biomasy są rośliny uprawiane $\mathrm{w}$ międzyplonie ścierniskowym wykorzystywanym jako zielony nawóz. Umożliwiają one wzrost aktywności biologicznej gleby oraz zwiększenie zawartości mikrobiologicznej biomasy glebowej (Perruci i Scarponi 1985; Piotrowska i Wilczewski 2012). Jak wynika z badań Lemańczyka i Wilczewskiego (2006) prowadzi to również do znacznego spadku nasilenia porażenia korzeni i podstawy źdźbła.

Uprawa w międzyplonie grochu siewnego umożliwia uzyskanie dodatkowej korzyści w postaci wzbogacenia gleby $\mathrm{w}$ azot pozyskiwany $\mathrm{w}$ procesie symbiozy $\mathrm{z}$ bakteriami rodzaju Rhizobium. Umożliwia on poprawę zaopatrzenia $\mathrm{w}$ ten składnik jęczmienia jarego uprawianego w kolejnym roku. Jednak rośliny intensywnie nawożone azotem są na ogół bardziej podatne na porażenie przez patogeny (Mathre 1997; Newton i wsp. 1998). Zatem wpływ międzyplonu na zdrowotność jęczmienia jest niejednoznaczny.

Celem pracy było określenie wpływu grochu siewnego uprawianego w międzyplonie ścierniskowym na porażenie korzeni, podstawy źdźbła, liści i kłosów jęczmienia jarego wysiewanego w następnym roku, z uwzględnieniem składu gatunkowego grzybów izolowanych z korzeni i podstaw źdźbeł z objawami chorobowymi.

\section{Materiały i metody / Materials and methods}

Badania polowe przeprowadzono w latach 2008-2011 w Szadłowicach $\left(52^{\circ} 50^{\prime} \mathrm{N}, 18^{\circ} 20^{\prime} \mathrm{E}\right)$ na czarnej ziemi typowej, należącej do kompleksu pszennego dobrego, klasy bonitacyjnej IIIa. Jednoczynnikowe doświadczenie wykonano w układzie losowanych bloków, w czterech powtórzeniach, na poletkach o powierzchni $250 \mathrm{~m}^{2}$. Czynnikiem doświadczenia był termin i sposób wprowadzenia biomasy międzyplonu do gleby: A jesienią - orką przedzimową; B - wiosną - talerzowaniem (międzyplon pozostawiony jako mulcz na zimę); $\mathrm{C}-$ kontrola - bez międzyplonu. Groch siewny wysiewano w międzyplonie ścierniskowym po zbiorze pszenicy ozimej w latach 2008, 2009 i 2010 oraz wykorzystywano jako zielony nawóz dla wysiewanego wiosną następnego roku jęczmienia jarego odmiany Tocada. Po skoszeniu międzyplonów (15 października do 3 listopada) w obiektach A i C wykonywano orkę przedzimowa, a wiosną glebę doprawiano agregatem uprawowym. Mulcz grochu (obiekt B) pocięto wiosną i wymieszano $\mathrm{z}$ glebą broną talerzową. Ziarno jęczmienia jarego zaprawiano preparatem Kinto Duo 080 FS (tritikonazol $20 \mathrm{~g} / \mathrm{l}+$ prochloraz kompleks z miedzią $60 \mathrm{~g} / \mathrm{l}$ ) i wysiewano na przełomie marca i kwietnia. Ponadto rośliny opryskiwano w fazie strzelania w źdźbło (GS 33 według skali Zadoksa i wsp. 1974) preparatem Capalo 337,5 SE (fenpropimorf $200 \mathrm{~g} / \mathrm{l}+$ epoksykonazol 62,5 g/l + metrafenon $75 \mathrm{~g} / \mathrm{l})$ w dawce $1,51 /$ ha.

Ocena zdrowotności jęczmienia dotyczyła porażenia korzeni, podstawy źdźbła, liści i kłosów. W fazie dojrzałości mlecznej (GS 75-77) oceniano stopień porażenia korzeni przez kompleks patogenów oraz podstawy źdźbła przez Oculimacula spp., Rhizoctonia spp., Fusarium spp. i Cochliobolus sativus (anamorfa Bipolaris sorokiniana), w skali $0-4^{\circ}$, gdzie 0 - oznaczało brak objawów, a 4 bardzo silne porażenie. Stopnie porażenia przeliczano na indeks chorobowy metodą Townsenda i Heubergera (1943). Procent porażonej powierzchni dwóch górnych liści jęczmienia określano w początkowej fazie dojrzewania ziarna jęczmienia (GS 71-73). Główną uwagę zwrócono na występowanie plamistości siatkowej (Pyrenophora teres), mączniaka prawdziwego zbóż i traw (Blumeria graminis), rynchosporiozy zbóż (Rhynchosporium secalis) i rdzy jęczmienia (Puccinia hordei). W tej fazie oceniano także procent powierzchni kłosów porażonych przez Fusarium spp. i C. sativus. Każdorazowo analizowano zdrowotność 25 losowo wybranych roślin $\mathrm{z}$ poletka. Uzyskane wyniki opracowano statystycznie, metodą analizy wariancji przy wykorzystaniu programu komputerowego AWAR, a istotność różnic określono przy użyciu półprzedziału ufności Tukeya dla $\mathrm{p} \leq 0,05$.

Ocenę zdrowotności korzeni i podstawy źdźbła uzupełniono analizą mikologiczną. Materiał do izolacji pobierano losowo z korzeni i podstaw źdźbeł wykazujących zmiany chorobowe, niezależnie od kombinacji doświadczenia. Wycinano po $100,5 \mathrm{~mm}$ fragmentów, z pogranicza tkanki zdrowej i chorej, oddzielnie z korzeni i podstaw źdźbeł. Tak przygotowany materiał płukano przez 45 minut pod bieżącą wodą, odkażano w $1 \%$ roztworze $\mathrm{AgNO}_{3}$ przez 15 sekund, a następnie płukano 
trzykrotnie po 1 minucie w sterylnej wodzie destylowanej i wykładano na pożywkę PDA (Potato Dextrose Agar) $\mathrm{z}$ dodatkiem streptomycyny $(50 \mathrm{mg} / \mathrm{l})$, znajdującej się w płytkach Petriego. Wyrastające kolonie grzybów odszczepiano na skosy agarowe i oznaczano według kluczy mikologicznych.

Aby potwierdzić przynależność gatunkową otrzymanych izolatów Oculimacula spp., Rhizoctonia spp., i wybranych gatunków Fusarium przeprowadzono reakcję PCR (polymerase chain reaction). W tym celu zastosowano specyficzne gatunkowo startery typu SCAR (sequence characterized amplified region), to znaczy TyV5F/R dla Oculimacula yallundae, Ta05F/R dla $O$. acuformis (Nicholson i wsp. 1997), Rc2F/R dla Rhizoctonia cerealis (Nicholson i Parry 1996), ITS1/GMRS-3 dla R. solani (Johanson i wsp. 1998), JIAF/R dla Gibberella avenacea (anamorfa $F$. avenaceum) (Turner i wsp. 1998), Fc01F/R dla Fusarium culmorum (Nicholson i wsp. 1998) i Fp82F/R dla F. poae (Parry i Nicholson 1996). Izolację całkowitego DNA (deoxyribonucleic acid) przeprowadzono według zmodyfikowanej metody Doyle i Doyle (1990). Do wykonania reakcji PCR (polymeraze chain reaction) zastosowano zestaw Taq PCR Core Kit (QIAGEN Inc., USA).

\section{Wyniki i dyskusja / Results and discussion}

Spośród chorób podsuszkowych najwyższą wartość indeksu chorobowego obserwowano dla porażenia korzeni (tab. 1). Słabszemu porażeniu uległa podstawa źdźbła, na której występowały głównie objawy zainfekowania przez Fusarium spp. i C. sativus. Objawy łamliwości źdźbła zbóż i ostrej plamistości oczkowej występowały w znacznie mniejszym stopniu. Stosunkowo duże nasilenie zgorzeli korzeni mogło wynikać z faktu, iż przedplonem jęczmienia jarego była pszenica ozima. Według wcześniejszych doniesień uprawa jęczmienia po pszenicy szczególnie sprzyja porażeniu korzeni (Lemańczyk i Wilczewski 2006). Za głównego sprawcę zgorzeli korzeni pszenicy uważa się Gaeumannomyces graminis (Bockus i wsp. 2010), którego to stwierdzono również na korzeniach analizowanego jęczmienia. W wyniku przeprowadzonej analizy mikologicznej z wykazujących objawy chorobowe korzeni jęczmienia jarego uzyskano łącznie 225 izolatów grzybów. Większość z nich stanowił G. graminis, którego udział wśród wszystkich wyizolowanych grzybów wynosił $24,4 \%$ (tab. 2). Również inni autorzy z porażonych korzeni jęczmienia często izolowali tego patogena (Mathre 1997; Lemańczyk i Wilczewski 2006; Kurowski i wsp. 2013). Prawdopodobnie krótki czas uprawy grochu w międzyplonie ścierniskowym okazał się niewystarczający, aby istotnie ograniczyć populację tego grzyba w glebie, czego wyrazem był brak zróżnicowania w nasileniu zgorzeli korzeni. Ponadto $\mathrm{z}$ korzeni jęczmienia izolowano również inne patogeny, w tym polifagiczne, atakujące nie tylko zboża, co także mogło istotnie ograniczyć znaczenie grochu w zmianowaniu. Izolowano dużo Glomerella graminicola $(16,9 \%)$, który w Polsce nie jest uznawany za jednego $z$ głównych patogenów jęczmienia, jednak może powodować zgorzel korzeni (Mathre 1997). Znaczną grupę stanowiły również grzyby, które w stadium konidialnym zaliczane są do rodzaju Fusarium (12,8\%). Wśród nich dominowały Haematonectria haematococca (anamorfa F. solani), F. culmorum i Gibberella intricans (anamorfa $F$. equiseti). Spośród potencjalnych patogenów znacznie mniej izolowano C. sativus (4,0\%) i $R$. solani $(0,9 \%)$. Dużą część stanowiły grzyby saprotroficzne dla jęczmienia.

Z podstawy źdźbła jęczmienia wykazującej zmiany chorobowe uzyskano łącznie 232 izolaty. Przede wszystkim izolowano grzyby, które w stadium konidialnym należą do rodzaju Fusarium (40,5\%), zwłaszcza F. culmorum $(19,0 \%)$ i G. avenacea $(9,9 \%)$. Spośród innych gatunków grzybów uznawanych za groźne patogeny zbóż stwierdzono także C. sativus $(15,5 \%)$. Z gatunków o niskim potencjale patogenicznym względem jęczmienia stosunkowo licznie izolowano G. graminicola (11,6\%), znacznie mniej Aureobasidium pullulans (3,4\%) i Microdochium bolleyi (2,2\%). Z porażonych źdźbeł mało izolowano $O$. yallundae $(3,0 \%)$, $R$. solani $(1,7 \%)$ i $R$. cerealis (1,3\%). Przynależność gatunkowa O. yallundae, $R$. solani, $R$. cerealis oraz wybranych izolatów $G$. avenacea, $F$. culmorum i $F$. poae potwierdzona została w wyniku przeprowadzonych reakcji PCR z zastosowaniem specyficznych gatunkowo starterów typu SCAR.

W badaniach własnych $O$. yallundae i Rhizoctonia spp. nie należały do dominujących patogenów uzyskanych z podstawy źdźbła jęczmienia jarego. Podaje się, iż zawartość DNA tych patogenów w tkankach zbóż wzrasta wraz z rozwojem rośliny (Nicholson i wsp. 2002; Ray i wsp. 2004). Być może dlatego w przypadku jęczmienia jarego, który cechuje się znacznie krótszym okresem wegetacji niż zboża ozime stwierdzono słabe nasilenie łamliwości źdźbła zbóż i ostrej plamistości oczkowej, na co wcześniej wskazywał również Korbas (2008). Ponadto O. yallundae oraz $R$. cerealis charakteryzują się wolnym wzrostem grzybni i prawdopodobnie nie zdążyły porazić tkanek w silniejszym stopniu (Ray i wsp. 2004; Korbas 2008; Głazek 2009; Lemańczyk i Kwaśna 2013). Słabe nasilenie tych chorób oraz fakt, iż patogeny je powodujące mogą przez pewien czas przeżyć w glebie saprotroficznie sprawił, że nie obserwowano znaczącego wpływu międzyplonu ścierniskowego na ich występowanie. Długość okresu wegetacji odgrywała mniejszą rolę przy porażeniu zbóż przez Fusarium spp., które cechują się znacznie szybszym wzrostem liniowym grzybni. Prawdopodobnie $\mathrm{z}$ tego względu obserwowano więcej objawów porażenia przez Fusarium spp. i C. sativus. Wprawdzie C. sativus cechuje się wolnym wzrostem, jednak pomimo to $\mathrm{w}$ Polsce uważany jest $\mathrm{za}$ jednego $\mathrm{z}$ głównych patogenów jęczmienia jarego (Knudsen i wsp. 1995; Baturo-Ciesniewska 2011; Kosiada 2013; Kurowski i wsp. 2013). Średnio dla trzech lat obserwacji porażenie podstawy źdźbła przez Fusarium spp. i C. sativus było istotnie ograniczane poprzez uprawę grochu w międzyplonie ścierniskowym, niezależnie od terminu i sposobu jego wprowadzenia do gleby. Również we wcześniejszych badaniach autorzy informują, że uprawa międzyplonów ścierniskowych może ograniczyć występowanie objawów powodowanych przez te patogeny (Lemańczyk i wsp. 2001). Stwierdzono, że wszelkie zabiegi, które zwiększają 
ogólną ilość mikroorganizmów w glebie ograniczają porażenie zbóż przez C. sativus ze względu na jego małą konkurencyjność wobec innych mikroorganizmów (Bailey i Lazarovits 2003). Nieco odmienne wyniki odnośnie znaczenia międzyplonu ścierniskowego uzyskali Gleń i wsp. (2007), którzy uprawiali pszenicę jarą po międzyplonie z bobiku. Podają oni, iż uprawa bezpłużna z mulczem istotnie sprzyja porażeniu podstawy źdźbła przez Fusarium spp. Ogólnie jednak stwierdzili lepszy stan fitosanitarny uprawy $\mathrm{z}$ zastosowaniem mulczu w porównaniu $\mathrm{z}$ uprawą $\mathrm{z}$ zastosowaniem tradycyjnej orki jesiennej.

Tabela 1. Zdrowotność jęczmienia jarego uprawianego po międzyplonie ścierniskowym

Table 1. Health status of spring barley cultivated after catch crop

\begin{tabular}{|c|c|c|c|c|c|c|}
\hline \multirow{2}{*}{$\begin{array}{c}\text { Część rośliny - metoda oceny } \\
\text { Part of plant - method } \\
\text { of assessing } \\
\end{array}$} & \multirow{2}{*}{$\begin{array}{l}\text { Choroba - patogen } \\
\text { Disease - pathogen }\end{array}$} & \multirow{2}{*}{$\begin{array}{l}\text { Międzyplon } \\
\text { ścierniskowy } \\
\text { Catch crop } \\
\end{array}$} & \multicolumn{3}{|c|}{ Rok-Year } & \multirow{2}{*}{$\begin{array}{l}\text { Średnio } \\
\text { Mean }\end{array}$} \\
\hline & & & 2009 & 2010 & 2011 & \\
\hline \multirow{4}{*}{$\begin{array}{l}\text { Korzeń } \\
\text { (indeks chorobowy w \%) } \\
\text { Root } \\
(\text { disease index in \%) }\end{array}$} & \multirow{4}{*}{$\begin{array}{l}\text { zgorzel korzeni } \\
\text { complex of fungi }\end{array}$} & $\mathrm{A}$ & 7,75 & 16,50 & 17,75 & 14,00 \\
\hline & & $\mathrm{B}$ & 8,75 & 16,00 & 22,50 & 15,75 \\
\hline & & $\mathrm{C}$ & 7,00 & 18,75 & 17,25 & 14,33 \\
\hline & & średnio - mean & 7,83 & 17,08 & 19,17 & 14,69 \\
\hline \multirow{12}{*}{$\begin{array}{l}\text { Podstawa źdźbła } \\
\text { (indeks chorobowy w \%) } \\
\text { Stem base } \\
\text { (disease index in \%) }\end{array}$} & \multirow{4}{*}{$\begin{array}{l}\text { Fusarium spp., } \\
\text { Cochliobolus sativus }\end{array}$} & $\mathrm{A}$ & $7,75 \mathrm{a}$ & 4,25 & 4,50 & $5,50 \mathrm{a}$ \\
\hline & & $\mathrm{B}$ & $9,25 \mathrm{ab}$ & 0,75 & 5,50 & $5,17 \mathrm{a}$ \\
\hline & & $\mathrm{C}$ & $15,8 \mathrm{~b}$ & 3,75 & 4,75 & $8,08 \mathrm{~b}$ \\
\hline & & średnio - mean & 10,9 & 2,92 & 4,92 & 6,25 \\
\hline & \multirow{4}{*}{$\begin{array}{l}\text { łamliwość źdźbła zbóż } \\
\text { Oculimacula yallundae }\end{array}$} & $\mathrm{A}$ & 3,00 & 6,25 & 0,25 & 3,17 \\
\hline & & $\mathrm{B}$ & 2,50 & 5,75 & 0,25 & 2,83 \\
\hline & & $\mathrm{C}$ & 4,00 & 4,75 & 0,25 & 3,00 \\
\hline & & średnio - mean & 3,17 & 5,58 & 0,25 & 3,00 \\
\hline & \multirow{4}{*}{$\begin{array}{l}\text { ostra plamistość oczkowa } \\
\text { Rhizoctonia spp. }\end{array}$} & $\mathrm{A}$ & 0,75 & 1,50 & 2,00 & 1,42 \\
\hline & & $\mathrm{B}$ & 0,25 & 0,50 & 0,50 & 0,42 \\
\hline & & $\mathrm{C}$ & 2,00 & 0,25 & 0,50 & 0,92 \\
\hline & & średnio - mean & 1,00 & 0,75 & 1,00 & 0,92 \\
\hline \multirow{16}{*}{$\begin{array}{l}\text { Liść } \\
\text { (procent powierzchni liścia } \\
\text { z objawami chorobowymi) } \\
\text { Leaf } \\
\text { (percentage of leaf surface } \\
\text { with disease symptoms) }\end{array}$} & \multirow{4}{*}{$\begin{array}{l}\text { plamistość siatkowa } \\
\text { Pyrenophora teres }\end{array}$} & $\mathrm{A}$ & 1,79 & 2,92 & 9,92 & 4,87 \\
\hline & & $\mathrm{B}$ & 2,04 & 3,29 & 8,75 & 4,69 \\
\hline & & $\mathrm{C}$ & 2,24 & 2,93 & 6,88 & 4,02 \\
\hline & & średnio - mean & 2,02 & 3,05 & 8,52 & 4,53 \\
\hline & \multirow{4}{*}{$\begin{array}{l}\text { mączniak prawdziwy } \\
\text { zbóż i traw } \\
\text { Blumeria graminis }\end{array}$} & $\mathrm{A}$ & 1,63 & $1,82 \mathrm{ab}$ & 1,54 & $1,66 \mathrm{ab}$ \\
\hline & & $\mathrm{B}$ & 1,69 & $2,25 \mathrm{~b}$ & 1,54 & $1,83 \mathrm{~b}$ \\
\hline & & $\mathrm{C}$ & 1,39 & $1,70 \mathrm{a}$ & 1,38 & $1,49 \mathrm{a}$ \\
\hline & & średnio - mean & 1,57 & 1,92 & 1,49 & 1,66 \\
\hline & \multirow{4}{*}{$\begin{array}{l}\text { rdza jęczmienia } \\
\text { Puccinia hordei }\end{array}$} & $\mathrm{A}$ & 0,00 & 0,31 & 0,02 & 0,11 \\
\hline & & $\mathrm{B}$ & 0,03 & 0,16 & 0,09 & 0,09 \\
\hline & & $\mathrm{C}$ & 0,04 & 0,42 & 0,12 & 0,19 \\
\hline & & średnio - mean & 0,02 & 0,30 & 0,08 & 0,13 \\
\hline & \multirow{4}{*}{$\begin{array}{l}\text { rynchosporioza zbóż } \\
\text { Rhynchosporium secalis }\end{array}$} & $\mathrm{A}$ & 0,00 & 0,00 & 0,00 & 0,00 \\
\hline & & $\mathrm{B}$ & 0,03 & 0,16 & 0,04 & 0,08 \\
\hline & & $\mathrm{C}$ & 0,01 & 0,01 & 0,13 & 0,05 \\
\hline & & średnio - mean & 0,01 & 0,06 & 0,06 & 0,04 \\
\hline \multirow{4}{*}{$\begin{array}{l}\text { Kłos (procent porażonej } \\
\text { powierzchni kłosa) } \\
\text { Spike (percentage of infected } \\
\text { surface of spike) }\end{array}$} & \multirow{4}{*}{$\begin{array}{l}\text { Fusarium spp., } \\
\text { Cochliobolus sativus }\end{array}$} & $\mathrm{A}$ & 0,83 & 0,08 & 2,71 & 1,21 \\
\hline & & $\mathrm{B}$ & 0,97 & 0,09 & 2,63 & 1,23 \\
\hline & & $\mathrm{C}$ & 0,92 & 0,04 & 2,13 & 1,03 \\
\hline & & średnio - mean & 0,91 & 0,07 & 2,49 & 1,16 \\
\hline
\end{tabular}

A - międzyplon przyorany jesienią - catch crop ploughed in autumn; B - międzyplon jako mulcz - catch crop as a mulch; $\mathrm{C}$ - kontrola, bez międzyplonu - control, without a catch crop

Wartości średnie w kolumnach oznaczone różnymi literami różnia się od siebie istotnie statystycznie $(\mathrm{p} \leq 0,05)-$ Mean values in the same columns and denoted by different letters vary statistically significantly among themselves $(\mathrm{p} \leq 0.05)$ 
Tabela 2. Grzyby występujące na korzeniach i podstawie źdźbła jęczmienia jarego z objawami chorobowymi - liczba izolatów

Table 2. Fungi occurring on spring barley roots and stem bases with disease symptoms - number of isolates

\begin{tabular}{|c|c|c|c|c|c|c|c|c|}
\hline \multirow[b]{2}{*}{ Takson - Taxon } & \multicolumn{4}{|c|}{ Korzenie - Roots } & \multicolumn{4}{|c|}{ Podstawa źdźbła - Stem base } \\
\hline & 2009 & 2010 & 2011 & $\begin{array}{c}\text { Razem } \\
\text { Total }\end{array}$ & 2009 & 2010 & 2011 & $\begin{array}{c}\text { Razem } \\
\text { Total }\end{array}$ \\
\hline Alternaria alternata (Fries.) Keiss. & 4 & 12 & 2 & 18 & 2 & 7 & 2 & 11 \\
\hline Aureobasidium pullulans (de Bary) Arnaud. & - & - & 1 & 1 & 1 & 5 & 2 & 8 \\
\hline Cladosporium herbarum (Pers.) Link. ex Fr. & - & - & 1 & 1 & - & - & - & - \\
\hline Clonostachys rosea f. catenulata (J.C. Gilman \& E.V. Abbott) Schroers & - & - & 1 & 1 & - & - & - & - \\
\hline Cochliobolus sativus (S. Ito \& Kurib.) Drechsler ex Dastur & - & 2 & 7 & 9 & 6 & 18 & 12 & 36 \\
\hline Epicoccum nigrum Link & 3 & 9 & 1 & 13 & - & 1 & - & 1 \\
\hline Fusarium culmorum (W.G. Smith) Sacc. & - & 2 & 5 & 7 & 4 & 21 & 19 & 44 \\
\hline F. oxysporum Schlecht. & - & - & 3 & 3 & 1 & 5 & 1 & 7 \\
\hline F. poae (Peck.) Wollenw. & - & - & 2 & 2 & 1 & 7 & 1 & 9 \\
\hline F. sporotrichioides Sherb. & - & - & - & - & 2 & 1 & - & 3 \\
\hline Gaeumannomyces graminis (Sacc.) Arx et Olivier & 9 & 27 & 19 & 55 & - & - & - & - \\
\hline Gibberella avenacea R.J. Cook & - & - & 3 & 3 & 6 & 9 & 8 & 23 \\
\hline G. intricans Wollenw. & 1 & - & 4 & 5 & 2 & 5 & 1 & 8 \\
\hline Glomerella graminicola D.J. Politis & 9 & 26 & 3 & 38 & 19 & 3 & 5 & 27 \\
\hline Haematonectria haematococca (Berk. \& Broome) Samuels \& Rossman & 1 & - & 6 & 7 & - & 2 & - & 2 \\
\hline Microdochium bolleyi (R. Sprague) de Hoog \& Herm.-Nijh. & - & - & 1 & 1 & 3 & 1 & 1 & 5 \\
\hline Mucor sp. & - & - & 1 & 1 & - & - & - & - \\
\hline Oculimacula yallundae (Wallwork \& Spooner) Crous \& W. Gams & - & - & - & - & 2 & 5 & - & 7 \\
\hline Penicillium spp. & 12 & 24 & 1 & 37 & 2 & 3 & 1 & 6 \\
\hline Periconia macrospinosa Lefebvre et Johnson Lefebvre et Johnson & - & - & 2 & 2 & - & - & - & - \\
\hline Rhizoctonia cerealis van der Hoeven & - & - & - & - & 1 & 2 & - & 3 \\
\hline R. solani Kühn & - & - & 2 & 2 & 1 & 1 & 2 & 4 \\
\hline Sarocladium strictum (W. Gams) Summerb. & - & - & 1 & 1 & - & 2 & 1 & 3 \\
\hline Trichoderma harzianum Rifai & - & - & 1 & 1 & - & - & - & - \\
\hline T. koningii Oudem. & - & - & 2 & 2 & 1 & 3 & 1 & 5 \\
\hline T. polysporum (Link ex Pers.) Rifai & - & - & 1 & 1 & 1 & - & - & 1 \\
\hline T. viride Pers. ex Gray & - & - & 1 & 1 & 4 & 1 & - & 5 \\
\hline Grzybnie nie zarodnikujące - Non-sporulating mycelia & 3 & 9 & 1 & 13 & 7 & 4 & 3 & 14 \\
\hline Łączna liczba izolatów - Total number of isolates & 42 & 111 & 72 & 225 & 66 & 106 & 60 & 232 \\
\hline
\end{tabular}

$\mathrm{Na}$ liściach jęczmienia najczęściej obserwowano objawy plamistości siatkowej. Wyraźnie mniej stwierdzono objawów mączniaka prawdziwego zbóż i traw, następnie rdzy jęczmienia i rynchosporiozy zbóż. Występowanie mączniaka prawdziwego zbóż i traw istotnie zależało od stosowania międzyplonu ścierniskowego. Najmniej objawów porażenia przez B. graminis obserwowano $\mathrm{w}$ kontroli, a stosowanie międzyplonu, zwłaszcza pozostawionego na zimę jako mulczu przyczyniało się do wzrostu porażenia. Wzrost porażenia obserwowany na jęczmieniu uprawianym po międzyplonie mógł wynikać ze zwiększonego zagęszczenia łanu. Jensen i Munk (1997) podają, iż stosowanie międzyplonu ścierniskowego może przyczynić się do wzrostu porażenia dzięki akumulacji azotu w glebie. Przyorana biomasa grochu uprawianego w międzyplonie zawierała dużo azotu, który później mógł być wykorzystywany przez jęczmień, o czym donoszą również Porta-Puglia i Aragona (1997). Newton i wsp. (1998) podają, że jęczmień silnie nawożony $\mathrm{N}$ jest bardziej wrażliwy na porażenie przez $B$. graminis, a dla innych patogenów ma to już mniejsze znaczenie. Ponadto większe zagęszczenie roślin może wpływać na nasilenie chorób również w sposób pośredni, między innymi poprzez zmianę mikroklimatu panującego w łanie. Zazwyczaj w gęstych zasiewach temperatura jest bardziej jednolita, panuje wyższa wilgotność powietrza, co znacznie sprzyja porażeniu roślin przez B. graminis (Salamati i Magnus 1997; Walters i wsp. 2012).

Na kłosach jęczmienia obserwowano objawy porażenia przez Fusarium spp. i C. sativus, które obejmowały średnio $1,16 \%$ ich powierzchni. Ich nasilenie nie zależało istotnie od stosowania międzyplonu. O porażeniu kłosów jęczmienia przez te patogeny donoszą również Bojko (2008), Baturo-Ciesniewska (2011) i Kosiada (2013). 
Mathre (1997) podaje, iż porażenie kłosów jęczmienia przez te patogeny nie zależy w większym stopniu od zmianowania.

\section{Wnioski / Conclusions}

1. Uprawa grochu siewnego w międzyplonie ścierniskowym, niezależnie od sposobu i terminu wprowadzenia biomasy do gleby, istotnie obniżała porażenie podstawy źdźbła jęczmienia jarego przez Fusarium spp. i C. sativus.

2. Do negatywnych aspektów uprawy międzyplonu ścierniskowego można zaliczyć wzmożone występowanie mączniaka prawdziwego zbóż i traw na jęczmieniu jarym uprawianym po międzyplonie ścier- niskowym, zwłaszcza pozostawionym na zimę jako mulcz.

3. $\mathrm{Z}$ porażonych korzeni jęczmienia jarego izolowano głównie G. graminis, następnie G. graminicola oraz grzyby, które w stadium konidialnym zaliczane są do rodzaju Fusarium, zwłaszcza H.haematococca, F. culmorum i $G$. intricans.

4. Na porażonych źdźbłach dominował: F. culmorum, C. sativus, G. graminicola i G. avenacea. Mniej izolowano: O. yallundae, $R$. solani, $R$. cerealis, A. pullulans i $M$. bolleyi.

Praca naukowa została sfinansowana ze środków Ministerstwa Nauki i Szkolnictwa Wyższego na naukę w latach 2008-2011 jako projekt badawczy nr N N310 144135 .

\section{Literatura / References}

Bailey K.L., Lazarovits G. 2003. Suppressing soil-borne diseases with residue management and organic amendments. Soil Till. Res. 72 (2): 169-180.

Baturo-Ciesniewska A. 2011. Genetic variability and pathogenicity among Polish isolates of Bipolaris sorokiniana (Cochliobolus sativus) derived from spring barley (Hordeum vulgare L.). J. Plant Pathol. 93 (2): 291-302.

Bockus W.W., Bowden R.L., Hunger R.M., Morrill W.L., Murray T.D., Smiley R.W. (eds.) 2010. Compendium of Wheat Diseases and Pests. 3rd ed. APS Press, St. Paul, MN, 171 pp.

Bojko A.K. 2008. Występowanie fuzariozy kłosa jęczmienia jarego w Białorusi i sposoby jego zwalczania. [Spread of Fusarium ear blight of spring barley in Belarus and the ways of it's limitation]. Prog. Plant Prot./Post. Ochr. Roślin 48 (3): 1021-1028.

Doyle J.J., Doyle J.L. 1990. Isolation of plant DNA from fresh tissue. Focus 12 (1): 13-15.

Gleń K., Gorczyca A., Kulig B. 2007. Healthiness of spring wheat Zebra and Bryza c.v. depending on applied agrotechnical measures. Chem. Inż. Ekol. 14 (11): 1175-1180.

Głazek M. 2009. Occurrence of eyespot on winter wheat in the Central-Southern region of Poland. J. Plant Prot. Res. 49 (4): $426-433$.

GUS 2012. Użytkowanie gruntów, powierzchnia zasiewów i pogłowie zwierząt gospodarskich w 2012 r., 188 ss.

Jensen B., Munk L. 1997. Nitrogen induced changes in colony density and spore production of Erysiphe graminis f. sp. hordei on seedlings of six spring barley cultivars. Plant Pathol. 46 (2): 191-202.

Johanson A., Turner H.C., McKay G.J., Brown A.E. 1998. A PCR-based method to distinguish fungi of the rice sheath-blight complex, Rhizoctonia solani, R. oryzae and R. oryzae-sativae. FEMS Microbiol. Lett. 162 (2): 289-294.

Knudsen I., Hockenhull J., Jensen D.F. 1995. Biocontrol of seedling diseases of barley and wheat caused by Fusarium culmorum and Bipolaris sorokiniana: effect of selected fungal antagonists on growth and yield components. Plant Pathol. 44 (3): $467-477$.

Korbas M. 2008. Epidemiologia łamliwości źdźbła pszenicy ozimej w Polsce. Rozpr. Nauk. Inst. Ochr. Roślin 18, 68 ss.

Kosiada T. 2013. Charakterystyka populacji Cochliobolus sativus (S. Ito \& Kurib.) Drechsler ex Dastur występującej w Wielkopolsce i na Kujawach. Bogucki Wydawnictwo Naukowe, 90 ss.

Kurowski T.P., Damszel M., Wysocka U., Sadowski T., Rychcik B. 2013. Zdrowotność jęczmienia jarego uprawianego w systemie konwencjonalnym i ekologicznym z uwzględnieniem konwersji. [Health status of spring barley grown in the conventional and organic farming systems including conversion]. Prog. Plant Prot./Post. Ochr. Roślin 53 (2): 351-355.

Lemańczyk G., Kwaśna H. 2013. Effects of sharp eyespot (Rhizoctonia cerealis) on yield and grain quality of winter wheat. Eur. J. Plant Pathol. 135 (1): 187-200.

Lemańczyk G., Skinder Z., Sadowski Cz. 2001. Impact of stubble intercrop and organic fertilisation on the health status of spring barley culm base. EJPAU, Ser. Agronomy 4 (2), \#7. http://www.ejpau.media.pl/volume4/issue2/agronomy/art-07.html [Accessed: 31.05.2002].

Lemańczyk G., Wilczewski E. 2006. Effects of intercrop plants in stubble and organic fertilization on the health of roots of spring barley in cereal crop rotations. Phytopathol. Pol. 40: 7-19.

Mathre D.E. 1997. Compendium of Barley Diseases. 2-nd ed. APS Press, St. Paul, MN, 90 pp.

Newton A.C., Thomas W.T.B., Guy D.C., Gaunt R.E. 1998. The interaction of fertiliser treatment with tolerance to powdery mildew in spring barley. Field Crops Res. 55: 45-56.

Nicholson P., Parry D.W. 1996. Development and use of a PCR assay to detect Rhizoctonia cerealis, the cause of sharp eyespot in wheat. Plant Pathol. 45 (5): 872-883.

Nicholson P., Rezanoor H.N., Simpson D.R., Joyce D. 1997. Differentiation and quantification of the cereal eyespot fungi Tapesia yallundae and Tapesia acuformis using a PCR assay. Plant Pathol. 46 (6): 842-856.

Nicholson P., Simpson D.R., Weston G., Rezanoor H.N., Lees A.K., Parry D., Joyce D. 1998. Detection and quantification of Fusarium culmorum and Fusarium graminearum in cereals using PCR assays. Physiol. Mol. Plant Pathol. 53 (1): 17-37.

Nicholson P., Turner A.S., Edwards S.G., Bateman G.L., Morgan L.W., Parry D.W., Marshall J., Nuttall M. 2002. Development of stem-base pathogens on different cultivars of winter wheat determined by quantitative PCR. Eur. J. Plant Pathol. 108 (2): $163-177$.

Parry D.W., Nicholson P. 1996. Development of a PCR assay to detect Fusarium poae in wheat. Plant Pathol. 45 (2): $383-391$.

Perucci P., Scarponi L. 1985. Effect of different treatments with crop residues on soil phosphatase activity. Biol. Fert. Soils 1 (2): 111-115. 
Piotrowska A., Wilczewski E. 2012. Effects of catch crops cultivated for green manure and mineral nitrogen fertilization on soil enzyme activities and chemical properties. Geoderma 189-190: 72-80.

Porta-Puglia A., Aragona M. 1997. Improvement of grain legumes - General part: diseases. Field Crops Res. 53: 17-30.

Ray R.V., Jenkinson P., Edwards S.G. 2004. Effects of fungicides on eyespot, caused predominantly by Oculimacula acuformis, and yield of early-drilled winter wheat. Crop Prot. 23 (12): 1199-1207.

Salamati S., Magnus H.A. 1997. Leaf blotch severity on spring barley infected by isolates of Rhynchosporium secalis under different temperature and humidity regimes. Plant Pathol. 46 (6): 939-945.

Townsend G.R., Heuberger J.W. 1943. Methods for estimating losses caused by diseases in fungicide experiments. Plant Dis. Rep. 27 (17): 340-343.

Turner A.S., Lees A.K., Rezanoor H.N., Nicholson P. 1998. Refinement of PCR-detection of Fusarium avenaceum and evidence from DNA marker studies for phylogenetic relatedness to Fusarium tricinctum. Plant Pathol. 47 (3): 278-288.

Walters D., Avrova A., Bingham I.J., Burnett F.J., Fountaine J., Havis N.D., Hoad S.P., Hughes G., Looseley M., Oxley S.J.P., Renwick A., Topp C.F.E., Newton A.C. 2012. Control of foliar diseases in barley: towards an integrated approach. Eur. J. Plant Pathol. 133 (1): $33-73$

Zadoks J.C., Chang T.T., Konzak C.F. 1974. A decimal code for the growth stages of cereals. Weed Res. 14 (6): $415-421$. 